\title{
THE WAY TO PREDICT THE EFFECTIVENESS OF BARIATRIC SURGERY IN PATIENTS WITH COMORBID OBESITY IN POST-PANDEMIC PERIOD
}

\section{The way to predict the effectiveness of bariatric surgery in patients with comorbid obesity in post- pandemic period}

M. I. Marushchak, I. Ya. Krynytska, I. Ya. Dzyubanovskyi I. Horbachevsky Ternopil National Medical University

e-mail: marushchak@tdmu.edu.ua

Summary. It is estimated that from 650 million to 2 billion adults worldwide, are overweight or obese, the numbers indicating epidemic levels of disease. In individuals, body mass index (BMI) exceeding $27 \mathrm{~kg} / \mathrm{m}^{2}$ is associated with a high risk of mortality and the presence of comorbid pathologies, in particular, atherogenic dyslipidemia, arterial hypertension $(A H)$, type 2 diabetes mellitus (T2D), thromboembolism, hepatic steatosis, etc. Preliminary data indicate that obesity is among key risk factors in severe and fatal cases of COVID-19, when comorbid with $A H$ and T2D.

The aim of this study - to analyze the possibility of developing an optimized model utilizing anamnestic, clinical, biochemical and genetic parameters for predicting the outcomes of bariatric surgery in the patients with obesity, type 2 diabetes mellitus (T2D) and/or arterial hypertension $(A H)$.

Results. Lifestyle changes and conservative treatment of obesity usually only result in a short-term effect, since the measures aiming to induce weight loss consign the person to a constant struggle with natural homeostatic processes. Recurrence of obesity in such patients is observed in $95 \%$ of the cases. Therefore, the International Association of Endocrinologists recommends that patients with a BMI greater than $40 \mathrm{~kg} / \mathrm{m}^{2}$, as well as with a BMI of 35.0 to $39.9 \mathrm{~kg} / \mathrm{m}^{2}$ and metabolic syndrome undergo a surgical treatment of obesity using minimally invasive techniques. At the same time, a number of issues associated with bariatric laparoscopic interventions remain unresolved, since these procedures are invasive and carry all the risks accompanying surgery, general anesthesia, and the postoperative recovery period. An innovative surgical approach, the X-ray endovascular bariatric embolization of the gastric arteries (BAE) is proposed as an alternative to laparoscopic intervention. However, the indications for the use of BAE are undefined, especially in the cases of comorbid obesity; there are no clear algorithms and guidelines for its use.

Conclusions. There have been no comprehensive studies of short-term, intermediate and long-term outcomes of BEA in Ukraine. This warrants the need to develop an optimal model for predicting the outcomes of
Прогнозування есрективності баріатричних оперативних втручань у пацієнтів із коморбідним перебігом ожиріння у постпандемічний період

М. І. Марущак, І. Я. Криницька, І. Я. Дзюбановський

Тернопільський національний медичний університет імені І. Я. Горбачевського МОЗ України

Резюме. В усьому світі за різними даними від 650 млн до 2 млрд дорослих осіб мають надмірну масу тіла або ожиріння, що досягає рівня епідемії. Індекс маси тіла

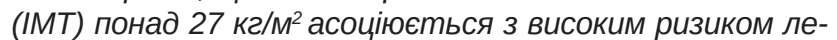
тальності та виникненням коморбідних патологій, зокрема атерогенної дисліпідемії, артеріальної гіпертензіі (АГ), цукрового діабету 2 типу (ЦД2), тромбоемболії, печінкового стеатозу та ін. У контексті глобальної пандемії COVID-19, ожиріння, ймовірно, є ключовим фрактором виникнення ускладнень та летальних випадків захворювання за умови коморбідних АГ та ЦД2.

Мета дослідження - проаналізувати можливість розробки оптимальної моделі прогнозування ефективності баріатричних оперативних втручань у пацієнтів 3 ожирінням і цукровим діабетом 2 типу (ЦД2) та/або артеріальною гіпертензією (АГ) на основі анамнестичних, клінічних, лабораторних та генетичних предикторів.

Результати. Зміна способу життя та консервативне лікування ожиріння мають короткотривалий ефект, оскільки людина перебуває у постійній боротьбі з природними гомеостатичними процесами, які спрямовані на протидію зниженню маси тіла. Рецидив ожиріння у таких пацієнтів спостерігається у 95 \% випадків. Тому згідно з рекомендаціями Міжнародних асоціацій ендокринологів, пацієнтам з IMT більше 40 кг/ $\mathrm{M}^{2}$, а також при

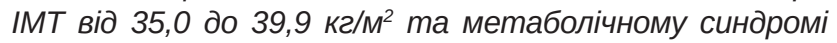
показано проведення хірургічного лікування ожиріння 3 застосуванням міні-інвазивних технологій. Водночас, ряд проблем баріатричних лапароскопічних втручань залишаються невирішеними, оскільки вони є інвазивними та асоціюються з ризиками, що пов'язані з власне операцією, загальним наркозом та післяопераційним періодом відновлення. Як альтернатива лапароскопічного втручання була запропонована інноваційна хірургічна технологія - рентгенендоваскулярна баріатрична емболізація артерій шлунка (БЕА). Проте показання для використання БЕА є нечіткими, особливо при коморбідному перебігу ожиріння, немає зрозумілих алгоритмів та інструкцій для ії застосування. Крім того, в Україні не проводилися комплексні дослідження короткотермінової, проміжної та віддаленої ефрективності БЕА у пацієнтів з ожирінням та коморбідною патологією, що об- 
both classical bariatric laparoscopic surgery with regulated gastric band and innovative BEA procedure in patients with comorbid obesity in post-pandemic period using anamnestic, clinical, biochemical and genetic predictors.

Key words: bariatric surgery; obesity; effectiveness.

\section{INTRODUCTION}

It is estimated that from 650 million to 2 billion adults worldwide, are overweight or obese, the numbers indicating epidemic levels of disease [1]. In Ukraine, just in children the prevalence of obesity increased from $0.08 \%$ in 2003 to $1.34 \%$ in 2016 , while 2016 Global Health Observatory data indicate that $24.1 \%$ of the adult population of our country are obese. In individuals, body mass index (BMI) exceeding $27 \mathrm{~kg} / \mathrm{m}^{2}$ is associated with a high risk of mortality and the presence of comorbid pathologies, in particular, atherogenic dyslipidemia, arterial hypertension $(\mathrm{AH})$, type 2 diabetes mellitus (T2D), thromboembolism, hepatic steatosis, etc. By 2025, total global health spending for treating complications linked to obesity is predicted to reach $\$ 1.2$ trillion [3]

Preliminary data indicate that obesity is among key risk factors in severe and fatal cases of COVID-19, when comorbid with $\mathrm{AH}$ and T2D. Adipose tissue can be considered as an endocrine organ that secretes adipokines, which affect inflammation and immune function. Therefore, increased production of pro-inflammatory cytokines in obese individuals can exacerbate the cytokine storm, which determines the progression of COVID-19. Additionally, [4] the ACE2 receptors, which are the gateway for SARS-CoV-2, are expressed in adipose tissue. Furthermore, obesity is associated with an increased risk of thromboembolism and COVID-19 is characterized by a prothrombotic state in the lungs [5]. On the other hand, there are no data on the potential impact of SARS-COV-2 infection on obesity.

The aim of this study is to analyze the possibility of developing an optimized model utilizing anamnestic, clinical, biochemical and genetic parameters for predicting the outcomes of bariatric surgery in the patients with obesity, type 2 diabetes mellitus (T2D) and/ or arterial hypertension $(\mathrm{AH})$.

\section{RESULTS AND DISCUSSION}

The mechanisms governing the development and progression of obesity and associated comorbid pa- грунтовує необхідність розробки математичної моделі прогнозування та порівняння ії ефрективності з класичними баріатричними лапароскопічними операціями.

Висновки. В Україні не проводилися комплексні дослідження короткотермінової, проміжної та віддаленої ефрективності БЕА, що обірунтовує необхідність розробки оптимальної моделі прогнозування ефрективності класичного баріатричного лапароскопічного оперативного втручання - регульованого бандажування шлунка та інноваційного - БЕА у пацієнтів із коморбідним ожирінням у постпандемічний період на основі анамнестичних, клінічних, лабораторних та генетичних предикторів.

Ключові слова: баріатрична хірургія; ожиріння; ефрективність.

thologies are not fully understood. From a pathogenesis point of view, obesity is a result of changes to neurochemical and reverse signaling stemming from the disequilibrium in energy regulation and leading to chronic metabolic inflammation associated with moderate hyperexpression of pro-inflammatory mediators and tissue modification which promotes infiltration by immune cells. Genetic and epigenetic mechanisms have also been invoked to help in understanding the pathophysiology of obesity [6]. Genomewide association study (GWAS) of obesity taking into account $\mathrm{BMI}$, waist-to-hip ratio and other quantitative indicators of excess weight, revealed more than 300 significant genetic polymorphism markers [7]. Current data on genetic predictors of obesity point to PPAR (receptors activated by peroxisome proliferators) gene mutations. However, there are almost no data on genetic predictors of obesity and the risk of comorbid pathology in Ukrainian population.

Lifestyle changes and conservative treatment of obesity usually only result in a short-term effect, since the measures aiming to induce weight loss consign the person to a constant struggle with natural homeostatic processes. Recurrence of obesity in such patients is observed in $95 \%$ of the cases. Therefore, the International Association of Endocrinologists recommends that patients with a BMI greater than $40 \mathrm{~kg} / \mathrm{m}^{2}$, as well as with a BMI of 35.0 to $39.9 \mathrm{~kg} / \mathrm{m}^{2}$ and metabolic syndrome undergo a surgical treatment of obesity using minimally invasive techniques [8]. In contrast to conservative treatments, bariatric surgery simultaneously addresses multiple anatomical and physiological processes, including the increased secretion of local satiety factors, altered transmission of nerve impulses to the gut and brain, intestinal microbiome remodeling, change in gastric evacuation and rapid delivery of nutrients to the gut. Bariatric surgery also results in significant alleviation of comorbid pathologies associated with obesity, including T2D and hypertension.

At the same time, a number of issues associated with bariatric laparoscopic interventions remain unre- 
solved, since these procedures are invasive and carry all the risks accompanying surgery, general anesthesia, and the postoperative recovery period [9]. An innovative surgical approach, the X-ray endovascular bariatric embolization of the gastric arteries (BAE) is proposed as an alternative to laparoscopic intervention [10]. It involves the introduction of spherical emboli into the arteria gastrica sinistra and/or arteria gastroepiploica. However, the indications for the use of BAE are undefined, especially in the cases of comorbid obesity; there are no clear algorithms and guidelines for its use. In addition, there have been no comprehensive studies of short-term, intermediate and long-term outcomes of BAE in patients with obesity and comorbid pathology in

\section{LITERATURE}

1. Pharmacotherapy of obesity: Available medications and drugs under investigation / E. O. Pilitsi, M. Farr, S. A. Polyzos [et al.] // Metabolism. - 2019. - Vol. 92. P. 170-192. DOI:10.1016/j.metabol.2018.10.010

2. The changes of activity of effector caspase cascade components in case of alimentary obesity in rats / M. Marushchak, I. Krynytska, L. Milevska [et al.] // Bangladesh Journal of Medical Science. - 2017. - Vol. 16 (2). - P. 252-258.

3. Efficacy and safety of semaglutide compared with liraglutide and placebo for weight loss in patients with obesity: a randomised, double-blind, placebo and active controlled, dose-ranging, phase 2 trial / P. M. O'Neil, A. L. Birkenfeld, B. McGowan [et al.] // Lancet. - 2018. - Vol. 392 (10148). P. 637-649. DOI:10.1016/S0140-6736(18)31773-2.

4. Orsi M. A. The lungs before and after COVID-19 pneumonia / M. A. Orsi, G. Oliva, M. Cellina // Am. J. Trop. Med. Hyg. - 2020. - Vol. 103 (1). - P. 6. DOI:10.4269/ ajtmh.20-0357.

5. Predictors for Severe COVID-19 Infection [published online ahead of print, 2020 May 30] / A. Bhargava, E. A. Fukushima, M. Levine [et al.] // Clin. Infect. Dis. 2020. - Vol. 674. DOI:10.1093/cid/ciaa674.

\section{REFERENCES}

1. Pilitsi E, Farr OM, Polyzos SA. Pharmacotherapy of obesity: Available medications and drugs under investigation. Metabolism. 2019;92: 170-92. DOI:10.1016/j. metabol.2018.10.010.

2. Marushchak M, Krynytska I, Milevska L, Miz A, Mialiuk $O$. The changes of activity of effector caspase cascade components in case of alimentary obesity in rats. Bangladesh Journal of Medical Science. 2017;16(2): 252-8.

3. O'Neil PM, Birkenfeld AL, McGowan B. Efficacy and safety of semaglutide compared with liraglutide and placebo for weight loss in patients with obesity: a randomised, doubleblind, placebo and active controlled, dose-ranging, phase 2 trial. Lancet. 2018;392(10148): 637-49. DOI:10.1016/ S0140-6736(18)31773-2.

4. Orsi MA, Oliva G, Cellina M. The lungs before and after COVID-19 pneumonia. Am J Trop Med Hyg. 2020;103(1): 6. DOI:10.4269/ajtmh.20-0357.
Ukraine. This underscores the need to develop a mathematical model for predicting its outcomes and comparing them to classical bariatric laparoscopic surgery.

\section{CONCLUSIONS}

There have been no comprehensive studies of short-term, intermediate and long-term outcomes of BEA in Ukraine. This warrants the need to develop an optimal model for predicting the outcomes of both classical bariatric laparoscopic surgery with regulated gastric band and innovative BEA procedure in patients with comorbid obesity in post-pandemic period using anamnestic, clinical, biochemical and genetic predictors.

6. The prognostic role of depression as a predictor of chronic somatic diseases manifestation / N. G. Neznanov, A. O. Kibitov, G. V. Rukavishnikov, G. E. Mazo // Ter. Arkh. - 2018. - Vol. 90 (12). - P. 122-132. DOI:10.26442/00403 660.2018.12.000019.

7. Goodarzi M. O. Genetics of obesity: what genetic association studies have taught us about the biology of obesity and its complications / M. O. Goodarzi // Lancet Diabetes Endocrinol. - 2018. - Vol. 6 (3). - P. 223-236. DOI:10.1016/S2213-8587(17)30200-0.

8. Practical Recommendations of the Obesity Management Task Force of the European Association for the Study of Obesity for the Post-Bariatric Surgery Medical Management / L. Busetto, D. Dicker, C. Azran [et al.] // Obes Facts. - 2017. - Vol. 10 (6). - P. 597-632. DOI:10.1159/000481825.

9. Albaugh V. L. Surgical treatment of obesity / V. L. Albaugh, N. N. Abumrad // F1000Res. - 2018. - (7). P. F1000. DOI:10.12688/f1000research.13515.1.

10. Bariatric embolization of the gastric arteries for the treatment of obesity / C. R. Weiss, A. J. Gunn, C. Y. Kim [et al.] // J. Vasc. Interv. Radiol. - 2015. - Vol. 26 (5). P. 613-624. DOI:10.1016/j.jvir.2015.01.017.

5. Bhargava A, Fukushima EA, Levine M. Predictors for Severe COVID-19 Infection. Clin Infect Dis. 2020;674. DOI:10.1093/cid/ciaa674.

6. Neznanov NG, Kibitov AO, Rukavishnikov GV, Mazo GE. The prognostic role of depression as a predictor of chronic somatic diseases manifestation. Ter Arkh. 2018;90(12): 122-32. DOI:10.26442/00403660.2018.12.00 0019.

7. Goodarzi MO. Genetics of obesity: what genetic association studies have taught us about the biology of obesity and its complications. Lancet Diabetes Endocrinol. 2018;6(3): 223-36. DOI:10.1016/S2213-8587(17)30200-0.

8. Busetto L, Dicker D, Azran C. Practical Recommendations of the Obesity Management Task Force of the European Association for the Study of Obesity for the Post-Bariatric Surgery Medical Management. Obes Facts. 2017;10(6): 597-632. DOI:10.1159/000481825. 


\section{Short reports}

9. Albaugh VL, Abumrad NN. Surgical treatment of obesity. F1000Res. 2018;7:F1000. DOI:10.12688/ f1000research.13515.1.
10. Weiss CR, Gunn AJ, Kim CY, Paxton BE, Kraitchman DL, Arepally A. Bariatric embolization of the gastric arteries for the treatment of obesity. J Vasc Interv Radiol. 2015;26(5): 613-24. DOI:10.1016/j.jvir.2015.01.017.

Received 04.06.20 